\title{
Assessment model of water harvesting and storage location using GIS and remote sensing in Al-Qadisiyah, Iraq
}

\author{
Marwah M. Al-Khuzaie ${ }^{1} \cdot$ Hussein Janna ${ }^{1} \cdot$ Nadhir Al-Ansari $^{2}$ (D) \\ Received: 10 August 2020 / Accepted: 19 October 2020 / Published online: 28 October 2020 \\ (C) The Author(s) 2020
}

\begin{abstract}
One of the important steps towards optimizing land productivity and water availability for the semi-arid and arid areas is the identification of potential sites for water harvesting. Therefore, this paper uses the Geographical Information System (GIS) techniques to select the optimized sites for water harvesting in Al-Qadisiyah Governorate, Iraq. Geographic water management capabilities are applied as a spatial analysis model. Data from global data repositories are retrieved followed by rescaling them to a spatial resolution to acquire a manageable input data set. The Soil Conservation Service Curve Number (SCS-CN) model is used to calculate the potential runoff as an intermediate input. Multi-Criteria Evaluation techniques are adopted to identify the relative importance and suitability levels of the input parameters set to manage the water supply. The suitability for identifying irrigation pond and dam location(s) was considered in this study. To achieve this goal, the criteria for eligibility for water harvesting areas have been completed on the basis of the conditions in the study methods. Based on the hydrological and geomorphological standards of the study area, suitable sites for harvest areas were identified and it was divided into four classes in terms of their suitability for water harvesting, namely very low, low, moderate, and high suitable for water harvesting. It can be concluded that the findings of this research can be used to assist in water resources management as an efficient planning tool to ensure sustainable development of the water in Iraq who suffers from water shortages.
\end{abstract}

Keywords Water availability $\cdot$ Remote sensing $\cdot$ Clean water quality $\cdot$ Rainwater harvesting $\cdot$ Runoff $\cdot$ Multi-criteria $\cdot$ GIS

\section{Introduction}

Water is a significant and limited resource that has many uses. Global climate variability, growing population, and economic development increase the pressure on resources. Freshwater has become vulnerable to depletion and marginalization especially in semi-arid to arid zones when

Responsible Editor: Broder J. Merkel

Marwah M. Al-Khuzaie

marwah.alkhuzaie@qu.edu.iq

Hussein Janna

hussein.janna@qu.edu.iq

Nadhir Al-Ansari

nadhir.alansari@ltu.se

1 Civil Engineering Department, College of Engineering, University of Al-Qadisiyah, Al Diwaniyah, Al-Qadisiyah, Iraq

2 Department of Civil, Environmenta and Natural Resources Engineering, Lulea University, Luleå, Sweden rainfall rates are unstable. The Middle East is known as an arid to a semi-arid area where average annual rainfall does not exceed $166 \mathrm{~mm} /$ year (Al-Ansari, 1998). Due to this fact, water scarcity became an extremely important factor for the stability of the counties in the area and an integral element in its economic development and prosperity (Al-Ansari and Knutsson, 2011). Iraq relies on its water resources on the Tigris and Euphrates Rivers. The flow of these rivers started to decrease due to climate changes and the construction of dams within the upper parts of the catchments (Al-Ansari, 2016). One of the means to overcome this problem is using non-conventional water resources like waste water treatment and re-use as well as water harvesting (Haider et al., 2019).

Water harvesting has become an increasingly important practice due to global warming and the depletion of fresh water sources. Moreover, other issues that should be considered are the discharge of groundwater and pollution, the need to recharge groundwater through water harvesting, and the processes of collecting and storing rainwater for later use (Al Maliki et al., 2020). 
The accumulated rainwater is stored in reservoirs, ponds, and groundwater. Many academics, specialists, and nonspecialists have reinforced the use of water harvesting techniques because of their low cost and simple implementation to address the water crisis (Adham et al., 2018). These techniques represent the artificial nutrition used in the management of water resources around the world. In general, water harvesting involves the storage of water flow to recharge the shallow aquifers using these technologies with several advantages (Al-Abadi et al., 2017). One of the advantages is the fact that rainwater has relatively low level of pollutants; and therefore, it is recommended to be used in crop cultivation as in which there is no chlorine (Khattak et al., 2016). In addition, rainwater can supplement existing water supplies, such as groundwater and urban water, reducing the costs and meeting the basic water needs, and it also supports environmental protection efforts (Wen et al., 2019).

Several researches were carried out to see the validity of rainwater harvesting in different parts of northern Iraq. All data indicated that adequate quantities of water can be captured for use through using this technique (Zakaria et al., 2012, 2013, b, 2014; Al-Ansari et al., 2013, 2014). In this work, a different area within the southern part of Iraq is to be investigated.

In the governorate of Al-Qadisiyah, Iraq, farmers cannot obtain a permanent source of water. The lack of water in the Euphrates river has compensated by rainwater and groundwater (Gowing et al., 1999). The groundwater level in AlQadisiyah lands has gradually decreased (Ijaz et al., 2017). The soil salinity is gradually increased due to climate change and the drilling of random wells by farmers. This situation highlights the need to establish a rainwater storage system, which can then be used as an additional source of water during the dry seasons (Haddad et al., 2014).

There are several factors that affect the choice of suitable water harvesting sites (Boudaghpour et al., 2015). One of the decisive factors is the earth's slope; other factors include land use and soil type (Vijayakrishnan et al., 2016). The potential for runoff and proximity to the points of irrigation systems, drinking water, geology, drainage along the slope of the land, land use, and soil type are also criteria for determining appropriate water harvesting sites (Sayl et al., 2016). In addition to the above factors, rainfall, soil depth, and other environmental and socio-economic factors have been used to select soil permeability (McCredie et al., 2017). The potential of runoff, flow arrangement, and catchment area is a criterion for selecting convenient sites for different water harvesting/recharging areas (Krois and Schulte, 2014). As in the UK, appropriate harvesting areas have been identified using a GIS-based remote sensing support system (Mahmoud et al., 2014).
Specifically, researchers used sets of thematic classes, including excess rainfall, slope, curve number $(\mathrm{CN})$, soil texture, land use/land cover, remote sensing data, and limited field survey to determine the best location of the water. In a study in Iraq, specifically Erbil city, Hameed identified appropriate areas for irrigation using GIS and multi-criteria assessment. The analytical hierarchy analysis was used to estimate the weight of each factor (Prasad et al., 2014).

Multiple standards have been also used by other researchers. For example, Prasad et al. (2014) adopted this analysis to identify the ideal location for harvesting water at the Besangan watershed in the Ajmer area. The authors examined different layers to assess the weights of the standards, which included soil strength, slope, rainfall data, Landsat 8, geomorphology, histology, small community distribution, and flow streams. Mahmoud et al. (2014) identified the possible water harvesting sites by integrating the potential of continuous runoff in GIS frameworks to estimate the area's runoff potential. Krois and Schulte (2014) used the Soil Restoration Service Curve (SCS$\mathrm{CN})$ number as an effective method for identifying potential runoff areas in a semi-arid zone.

This paper aims to locate suitable water harvesting areas in Al-Qadisiyah Governorate using remote sensing techniques with GIS. The use of appropriate factors and criteria affecting the considered area has not been exploited in the open literature. The results of this study will help the decision makers to add new aspects to develop water management plans in AlQadisiyah Governorate and ultimately the solution of water scarcity in the city.

\section{Study area}

The study area, Al-Qadisiyah Governorate, is one of the governorates of Iraq. It is in the plains center-south of the country. The Euphrates river and one of its main tributaries called the Shamiya river, both are run through this governorate. It is located between $31^{\circ} 20^{\prime} 00^{\prime \prime} \mathrm{N}$ to $32^{\circ}$ $20^{\prime} 00^{\prime \prime} \mathrm{N}$ latitude and $44^{\circ} 40^{\prime} 00^{\prime \prime} \mathrm{E}$ to $45^{\circ} 40^{\prime} 00^{\prime \prime} \mathrm{E}$ longitude as shown in Fig. 1. The overall area of the considered site is $8957.682 \mathrm{~km}^{2}$. The highest and lowest altitudes are $96 \mathrm{~m}$ and $-47 \mathrm{~m}$ respectively, with mean sea level. The location of the considered study area is in the dry climate region having an average temperature of $25{ }^{\circ} \mathrm{C}$ with an annual precipitation of $180 \mathrm{~mm}$ (please see Iraqi Agro met network https://agromet.gov.iq/en/). The observation of precipitation was almost done in July as in this period the cumulated annual precipitation falls by around $70 \%$. The geomorphology of the considered site comprises of a flat plain. Soil textures are loam, 
Fig. 1 Case study showing AlQadisiyah Governorate is one of the governorates of Iraq

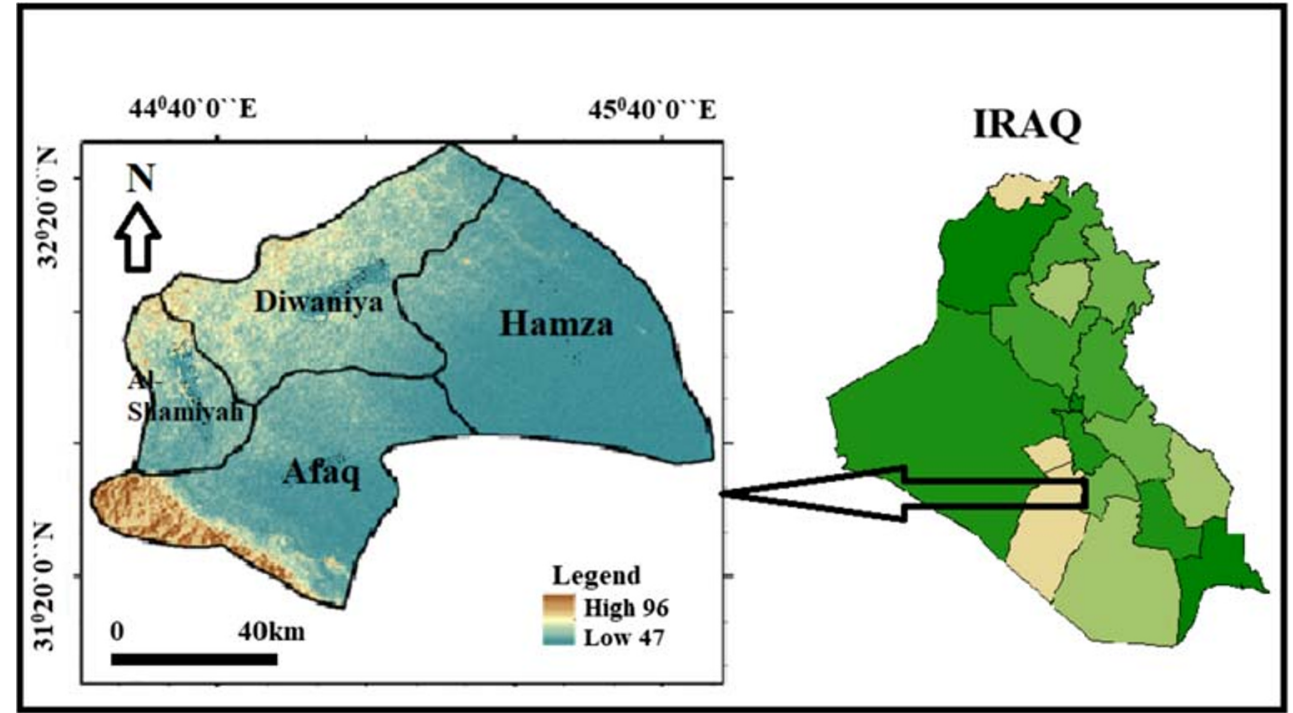

sandy loam, and silty loam. The land use of this area includes four types, namely $50 \%$ rangeland, $30 \%$ agriculture, $10 \%$ settlement, and $10 \%$ mining according to the files of the Ministry of Municipalities and Public Works, Al-Diwaniyah sewerage directorate.

\section{Methodology}

It is of interest to use a process for identifying an additional source of water to represent a rainwater storage system in which the Iraqi climate, specifically Al-Qadisiyah Governorate, is considered. The workflow in Fig. 2 shows the detail of the model used in this study. The next subsections represented by the data collection, preparation, and analysis introduce the description of the main parts of the used workflow.

\section{Data collection}

To determine potential surface rainwater harvesting sites, which is the main aim of this work, the findings are obtained by using spatial differences in landscape characteristics like the land cover (https://earthexplorer.usgs.gov.), slopes, digital elevations DEM (https://vertex.daac.asf. alaska.edu/\#.), rainfall (please see Iraqi Agro met network https://agromet.gov.iq/en/), soils, and land use (according to the files of the Ministry of municipalities and public works, Al-Diwaniyah sewerage directorate). Figure 2 illustrates the methodology used in this study, consisting of three phases namely pre-treatment, mapping, and major processing of potential harvest sites. The pre- treatment includes collecting primary data, for example, coordinates of the principle highlights of the considered site and on-site soil analysis. In terms of the secondary data, it includes collecting the observable meteorological information (precipitation) by the cooperation with the meteorological services department and various forms of government departments and other necessary data obtained from Al-Diwaniyah sewerage directorate which belongs to the Ministry of Municipalities and Public Works.

\section{Data preparation and analysis of pre-processing}

The sets of spatial data are used in this study as follows: digital elevation ALOS satellite (DEM) of 12-m resolution developed for the preparation of digital elevation model, download the image in November 2018, slope (varied between 5 and $16 \%$ ), aspect map with watershed deranges (high drainage density with suitable rainfall), and stream order of the area. Other sets of spatial data that should be considered are administration boundary, road, land used, soil type, agricultural land, topographic map, surface water, satellite image Landsat 8 with a $30-\mathrm{m}$ resolution, and precipitation (https:// earthexplorer.usgs.gov.) download in September 2018 for the clarity of the atmosphere during this period.

Several zones lacked point measurements of rainfall and actual evapotranspiration. An inverse distance weighting (IDW) algorithm is available in the ArcGIS Geostatistical Analyst and uses points represented by the weather stations' round boundaries for estimating any non-sampled position, according to the hypothesis that things further away are less similar compared to those near one another. Therefore, it is used to estimate the amount of rainfall as shown in Fig. 5a and 
Fig. 2 Methodology model study

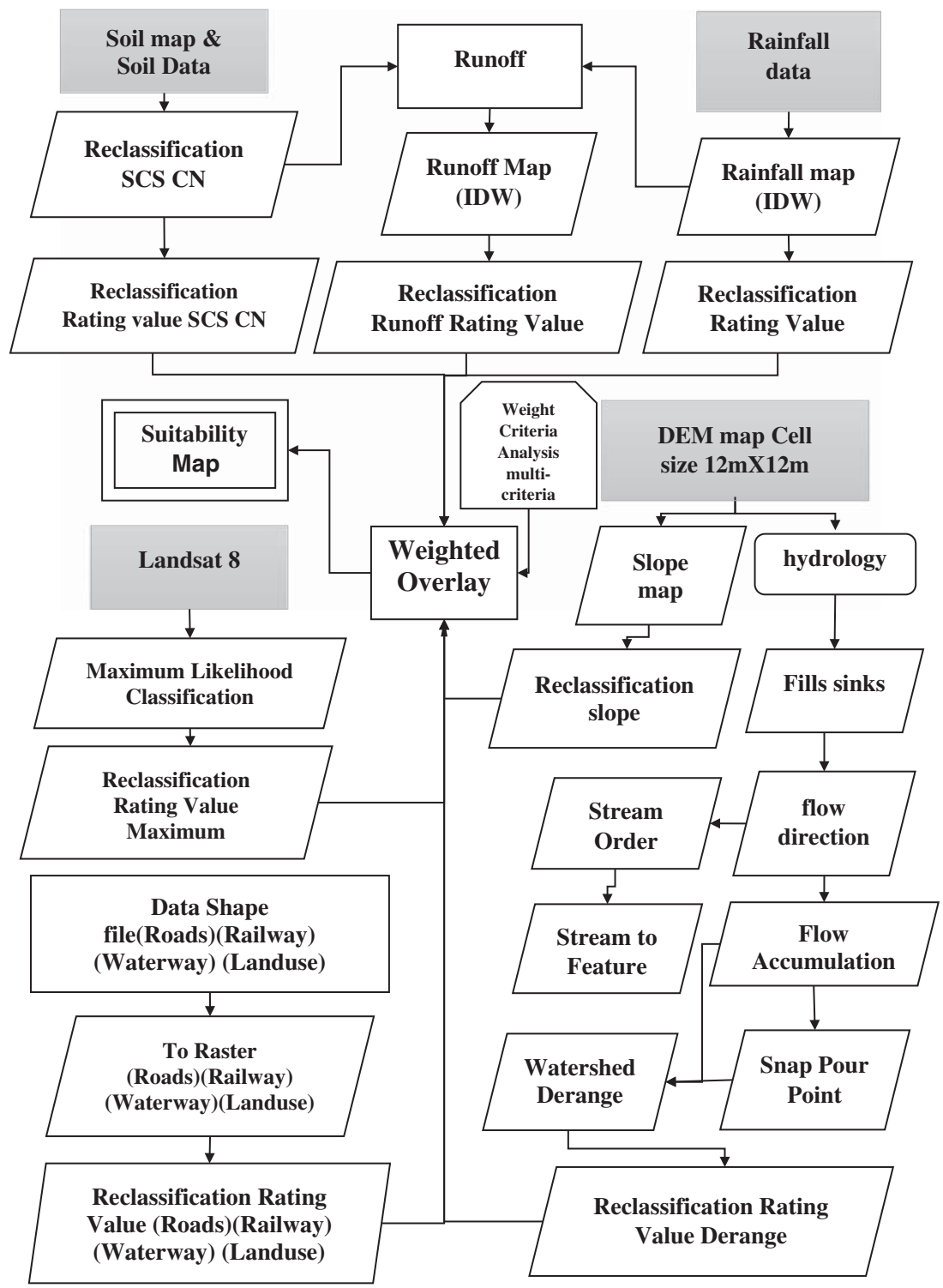

evapotranspiration in the study area shown in Fig. 5b. The interpolation result revealed that the average annual rainfall of the study area was $150 \mathrm{~mm}$ for the period of 2000-2019. Figure 5 illustrates the average rainfall and evapotranspiration in the study area for the period of 2000-2019 according to the weather stations under the Iraqi Agro met Network (https:// agromet.gov.iq/en/). The watershed drainage, and stream order and slope of the study area were derived from the ALOS satellite DEM. Land use was classified by conducting a supervised classification in the GIS. A maximum likelihood algorithm is adopted to assort the Landsat 8 images using the reference (https://earthexplorer.usgs.gov.) shown in Fig. 8. In this work, runoff depth is estimated utilizing the SCS CN model. This model is selected as it has frequently been adopted to predict the surface runoff for a known precipitation event (https://agromet.gov.iq/en/). This method has also been used for determining the runoff availability to assess the potential to harvest rainwater (Boudaghpour et al.,

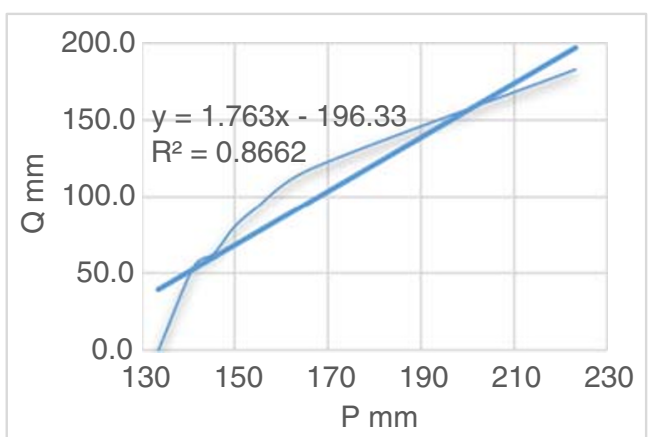

Fig. 3 Rainfall-runoff coefficient 


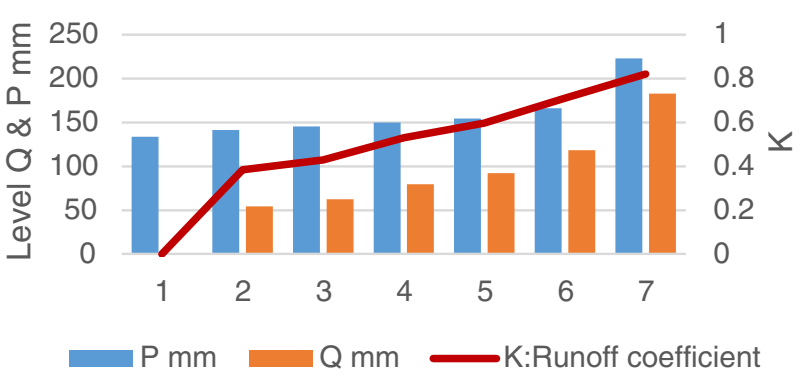

Fig. 4 Comparison of the current results ( $K$ : runoff coefficient of current results) with previous studies (Kv: runoff coefficient of previous studies) (Buraihi and Shariff 2015)

2015). Therefore, the SCS CN model is selected for the current work to evaluate the runoff depth. To derive curve numbers required to predict the runoff depth of the considered site, maps of land cover/land use and soil texture are used. These maps are reclassified into a group of hydrological soil according to the classification system of the United States Department of Agriculture. The Soil Conservation Service model for rainwater water harvesting [9] is used to evaluate the runoff depth. This equation can be expressed as follows:

$Q=\left(P-I_{a}\right)^{2}\left(\left(P-I_{a}\right)+S\right)^{-1}$
$Q$ represents the runoff depth in millimeters.

$S$ represents the highest potential retention in millimeters.

$P$ represents the rainfall in millimeters.

$I_{a}$ represents the initial abstraction in millimeters.

$I_{a}=0.3 S$ is recommended for the study area (Prasad et al., 2014).

$S=\frac{25400}{\mathrm{CN}}-254$

$S$ represents the potential maximum retention after the starting of runoff in $\mathrm{mm}$.

$\mathrm{CN}$ represents the curve number.

$\mathrm{CN}$ was estimated by matching the soil map and land cover on the rainfall-runoff processes by GIS with vector data layers. The soil types were classified in the hydrological soil group based on the soil texture and the infiltration rates for each soil type. It ranges from 1 , which represents $100 \%$ rainfall infiltration and no production of effective runoff, to 100 , which represents $0 \%$ rainfall infiltration and high production of effective runoff. Low values of the curve number illustrate low runoff potential while high values of the curve number illustrate high runoff potential. To combine the effect of each criterion into one map, the weighted overlay tool is adopted in this study. This involves assigning values of weights/scale

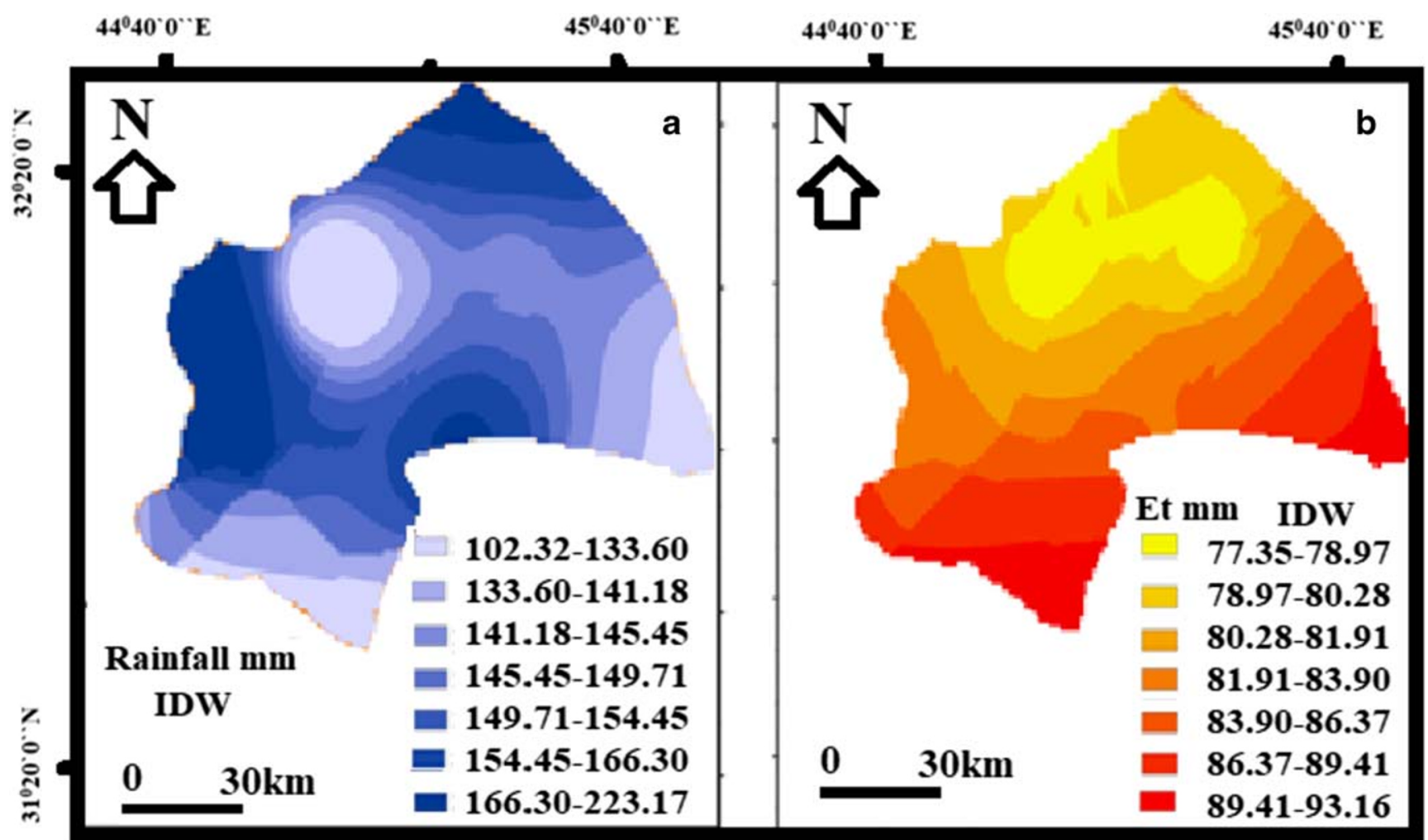

Fig. 5 Interpolation method used (IDW) map for rainfall (a) and interpolation method used (IDW) map for evapotranspiration from point weather stations under the Iraqi Agro met Network (b) 
related to every criterion, including its effect on the total suitability model. The annual runoff coefficient $(K)$, shown in Eq. 3 , is derived based on the annual flow depth. This annual flow factor gives an indication of the percentage of precipitation that was converted into an effective flow. Figure 6 shows the value of the runoff coefficient which is not less than 0.5 .

$K=\frac{\text { Total Seasonal Runoff }(\mathrm{mm})}{\text { Total Seasonal Rainfall }(\mathrm{mm})}$

\section{Results and discussion}

A high positive correlation was found between runoff depth and the amount of rainfall. The linear relationship can be expressed as $y=1.763 x-196.33$, where $x$ is the annual mean rainfall and $y$ is the runoff depth. In addition, the value of $R^{2}$ is relatively high (0.93) which means $93 \%$ variations in dependent variable $Y$ are explained by the independent variables present in our model as shown in Figs. 3 and 4 (Abdulla \& Al-badranih (2000), Najmaddin et al. (2017), Hussein \& Othman (1988)). Figure 5 illustrates the strong correlation between the two factors. Soil texture as the main parameter was used along with other parameters to evaluate the runoff depth using the $\mathrm{CN}$ approach. Runoff depth can reasonably be considered of high priority and weight because it was derived from the main parameters as shown in Fig. 6.

The areas, having a large runoff depth equal to or more than $183.3 \mathrm{~mm} /$ annum with a large coefficient of annual runoff limited from about 0.72 up to 0.82 , are located in high drainage density.
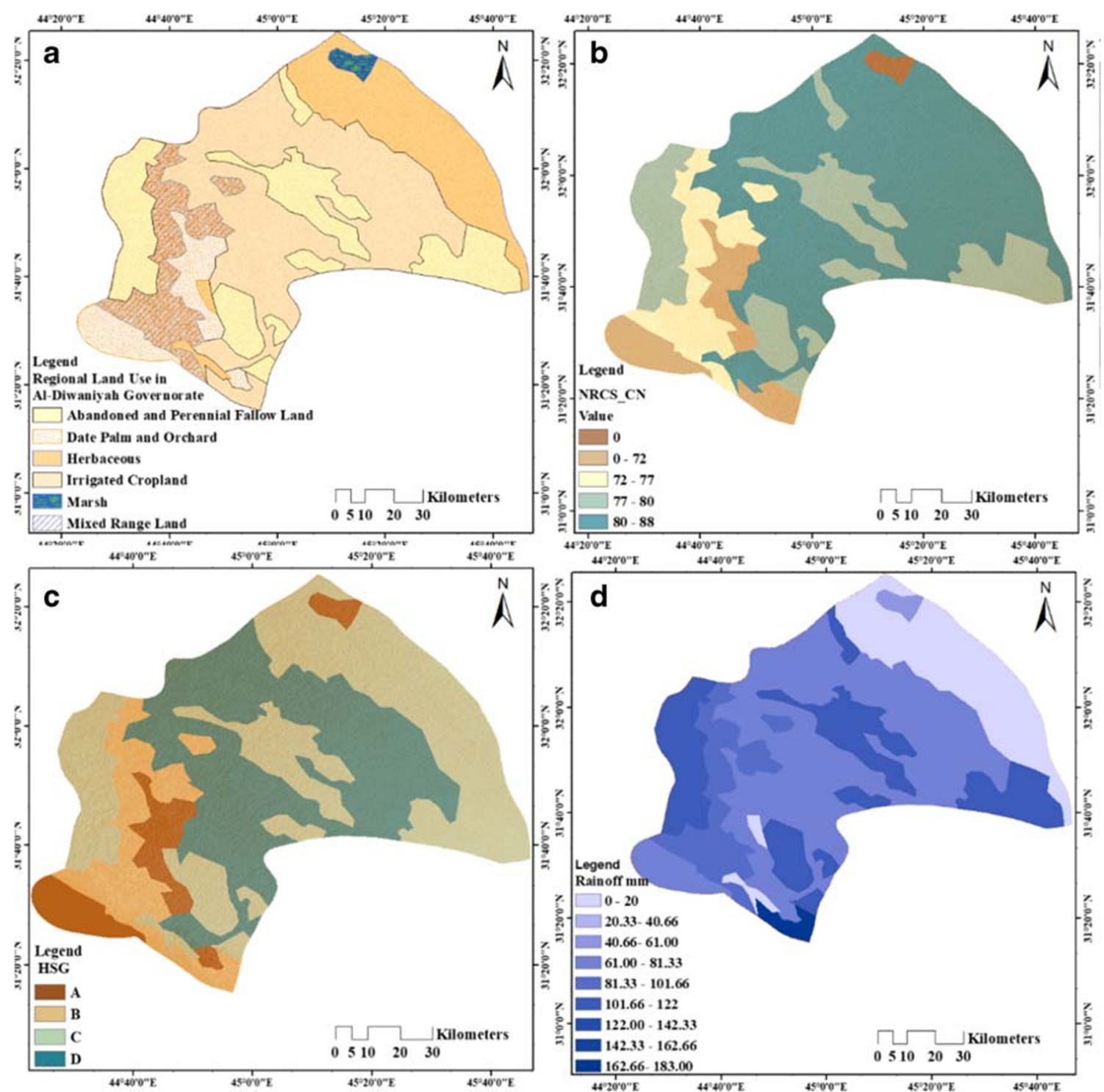

Fig. 6 Map of regional land use (a), NRCS map showing soils divided into four hydrologic soil groups (b) with map runoff curve number CN (c) and map runoff $(\mathbf{d})$ 

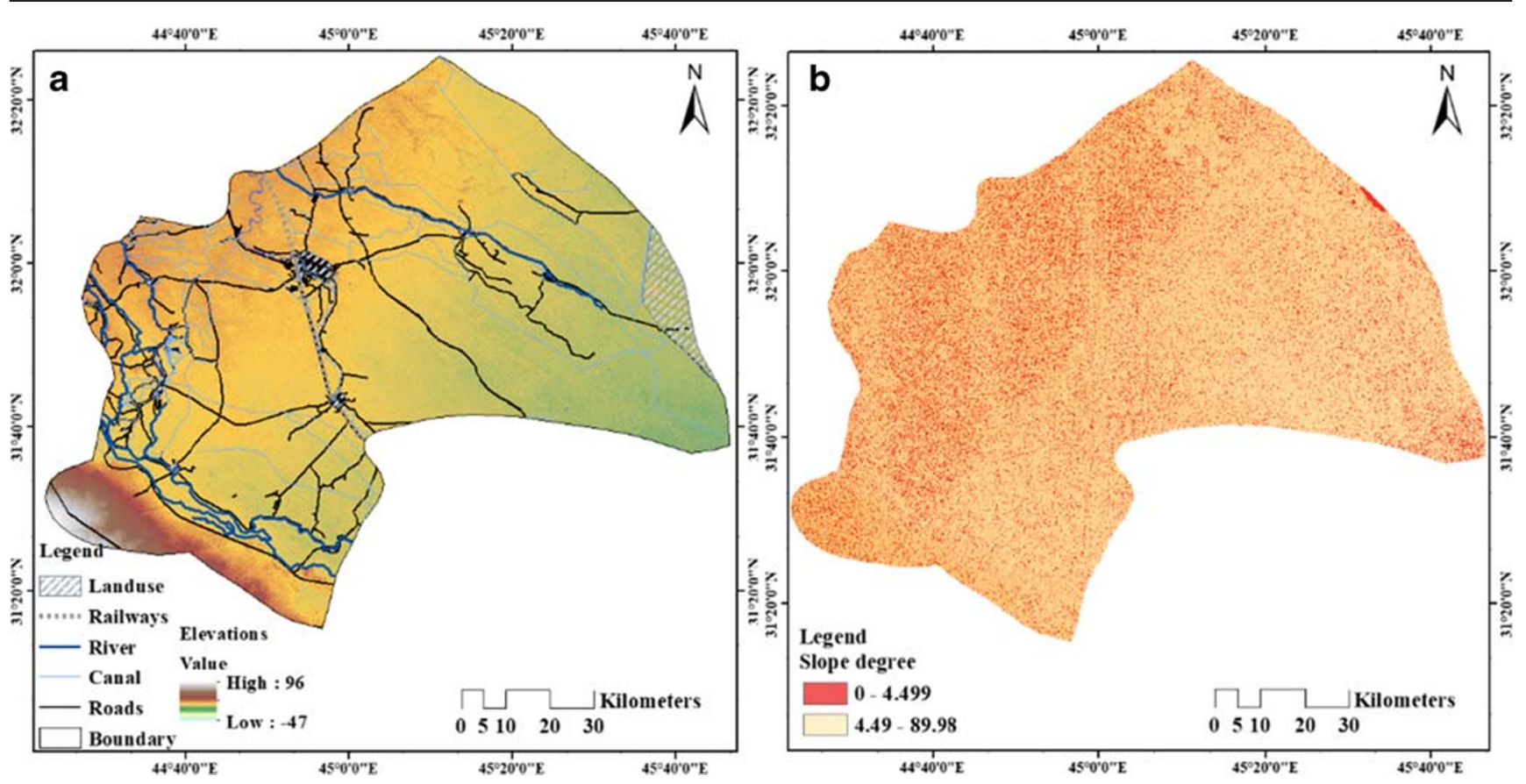

Fig. 7 Map of land use, railway, river, canal, roads, and elevations (a) with map slope degree (b)

The current model was validated by comparing the coefficient $(K)$ and $(\mathrm{Kv})$ for the current study, with the reference from Buraihi and Shariff (2015). The value of the trendline of the coefficient of determination is $\left(R^{2}\right)=$ $93.71 \%$ for the current study while the equivalent value
(Buraihi and Shariff 2015) is $\left(R^{2}\right)=99.12 \%$. This good agreement gives confidence to use the current model.

This study considered the suitability of sites to identify agricultural ponds and dams. To achieve this goal, the criteria for eligibility for water harvesting areas have been completed
Fig. 8 Map of land use was classified, using maximum likelihood algorithm, by conducting a supervised classification in the GIS

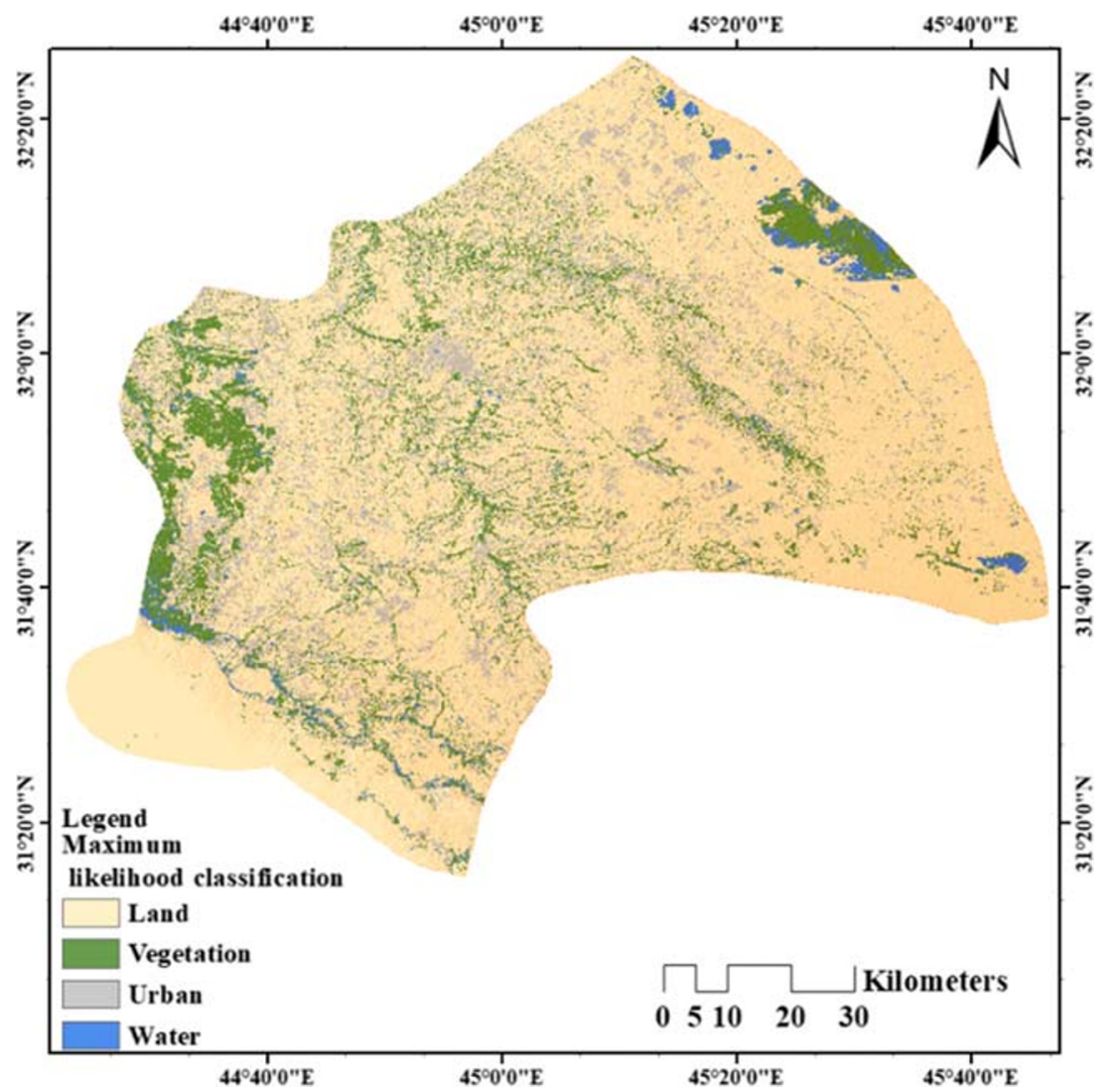


Fig. 9 Map suitability level for the case study

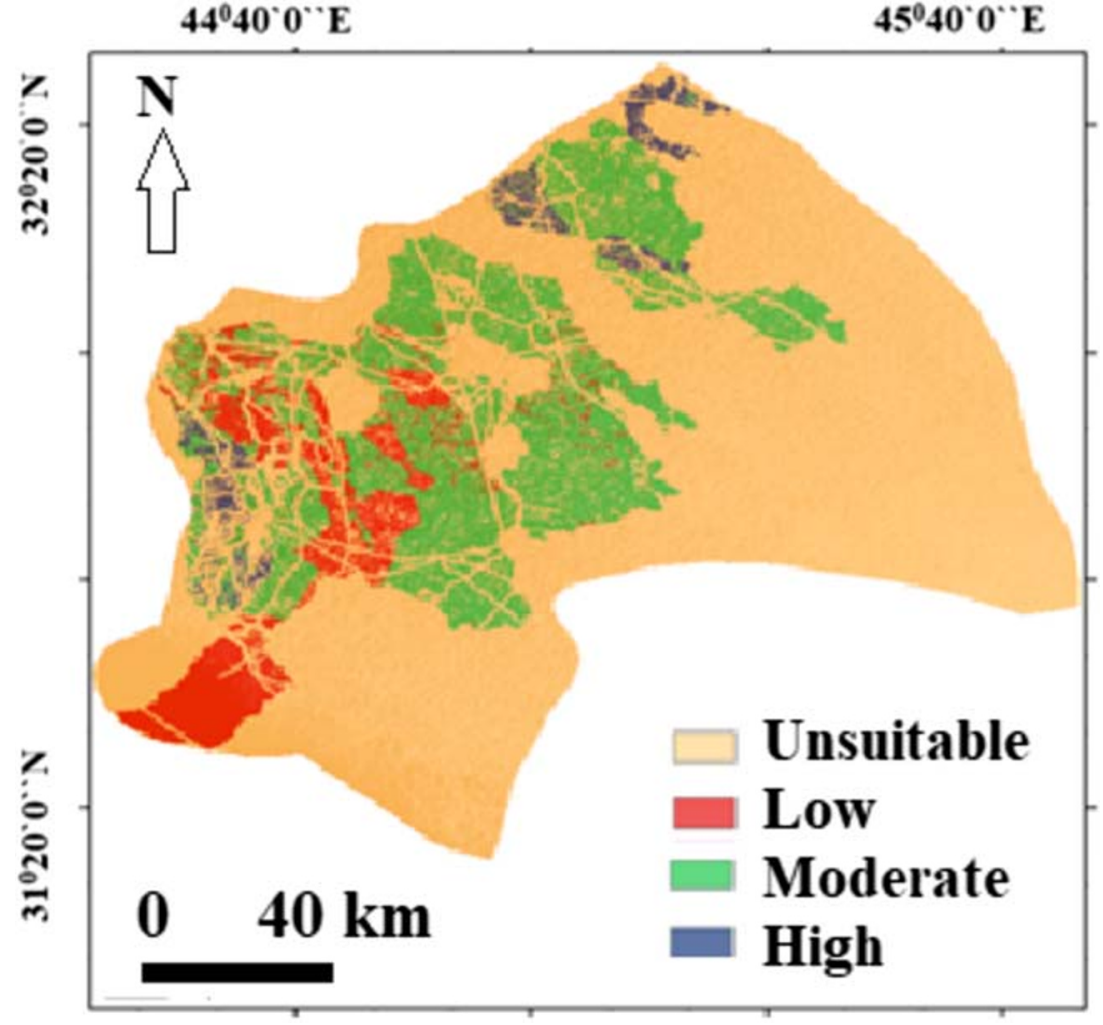

on the basis of the conditions in the study methods (Figs. 7 and 8 ). Based on the hydrological and geomorphological standards of the study area, the suitability for identifying irrigation pond and dam location(s) was considered in this study. To achieve this goal, the criteria for eligibility for water harvesting areas have been completed on the basis of the conditions in the study methods. Based on the hydrological and geomorphological standards of the study area, suitable sites for harvest areas were identified and it was divided into four classes in terms of their suitability for water harvesting, namely very low, low, moderate, and high suitable for water harvesting. Figure 9 shows a map of the relevance of different harvest areas.

\section{Conclusions}

The current study used remote sensing techniques and geographic information systems to select suitable water harvesting areas in Al-Qadisiyah Governorate, Iraq. These techniques were combined with a multi-criteria evaluation method in conjunction with other criteria to obtain the best decision. The selection of suitable water harvesting areas relies on the accuracy and quality of the available data, including the methods used to collect, process, and deliver the data. The availability of highquality data and the distribution of weights are highly reliable and efficient. The results led to classify the studied area into four classes in terms of the suitability for the water harvesting, namely very low, low, moderate, and high suitable for water harvesting. This research will contribute to the enhancement of the available water resources in the country if the selected sites will be utilized for water harvesting. This will contribute to the sustainable socio-economic development of Al-Qadisiyah Governorate, Iraq. Rainwater harvesting is an alternative (and for many reasons better) water supply to the normal surface water-based supplies from reservoirs or groundwater-based supplies from wells tapped into underground aquifers. Rainwater harvesting helps manage stormwater runoff to prevent erosion, flooding, and poor water quality in our lakes and streams. It is recommended to perform further research to analyze the chosen sites to test the sub-surface layers and suitability of the soil for water harvesting purposes. A field visit plays a significant role in terms of validation.

Funding Open access funding provided by Lulea University of Technology.

Open Access This article is licensed under a Creative Commons Attribution 4.0 International License, which permits use, sharing, adaptation, distribution and reproduction in any medium or format, as long as you give appropriate credit to the original author(s) and the source, provide a link to the Creative Commons licence, and indicate if changes were made. The images or other third party material in this article are included in the article's Creative Commons licence, unless indicated otherwise in a credit line to the material. If material is not included in the article's Creative Commons licence and your intended use is not permitted by statutory regulation or exceeds the permitted use, you will need to obtain permission directly from the copyright holder. To view a copy of this licence, visit http://creativecommons.org/licenses/by/4.0/. 


\section{References}

Abdulla F, Al-badranih L (2000) Application of a rainfall-runoff model to three catchments in Iraq. Hydrol Sci J 45(1):13-25. https://doi.org/ $10.1080 / 02626660009492303$

Adham A, Sayl KN, Abed R, Abdeladhim MA, Wesseling JG, Riksen M, Fleskens L, Karim U, Ritsema CJ (2018) A GIS-based approach for identifying potential sites for harvesting rainwater in the Western Desert of Iraq. Int Soil Water Conserv Res 6:297-304. https://doi. org/10.1016/j.iswcr.2018.07.003

Al Maliki, A. A., Abbass, Z. D., Hussain, H. M.,'Al-Ansari, N., 2020, Assessment of the groundwater suitability for irrigation near $\mathrm{Al}$ Kufa City and preparing the final water quality maps using spatial distribution tools. Environ Earth Sci 79:330. https://doi.org/10. 1007/s13369-018-3627-y, 4920

Al-Abadi AM, Shahid S, Ghalib HB, Handhal AM (2017) A GIS-based integrated fuzzy logic and analytic hierarchy process model for assessing water-harvesting zones in northeastern Maysan Governorate. Iraq Arab J Sci Eng 42:2487-2499. https://doi.org/ 10.1007/s13369-017-2487-1

Al-Ansari, N.A., 1998, Water resources in the Arab countries: problems and possible solutions, UNESCO international conf. (water: a looming crisis), Paris, pp 367-376

Al-Ansari NA (2016) Hydropolitics of the Tigris and Euphrates basins. Eng 8(3): 140-172

Al-Ansari NA, Abdellatif M, Zakaria S, Mustafa Y, Knutsson S (2014) Future prospects for macro rainwater harvesting $(\mathrm{RWH})$ technique in northeast Iraq. J Water Resour Prot 6(5):403-420

Al-Ansari NA, Knutsson S (2011) Toward prudent management of water resources in Iraq. J Adv Sci Eng Res 1:53-67

Al-Ansari, N.A., Zakaria, S.,Mustafa, Y.T., Ahmad, P.,Ghafour, B. and Knutsson, S., 2013, Development of water resources in Koya City, Iraq, 1st International Symposium on Urban Development of Koya, December 16-17, 2013, Koya University

Boudaghpour S, Bagheri M, Bagheri Z (2015) Estimation of flood environmental effects using flood zone mapping techniques in Halilrood Kerman. Iran Arab J Sci Eng 40:659-675. https://doi.org/10.1007/ s13369-014-1536-2

Buraihi FH, Shariff ARM (2015) Selection of rainwater harvesting sites by using remote sensing and GIS techniques: a case study of Kirkuk, Iraq. Jurnal Teknologi 76(15):75-81. https://doi.org/10.11113/jt. v76.5955

Gowing JW, Mahoo HF, Mzirai OB, Hatibu N (1999) Review of rainwater harvesting techniques and evidence for their use in semi-arid Tanzania. Tanzan J Agric Sci 2(2):171-180 https:/www.ajol.info/ index.php/tjags/article/view/115921

Haddad M, Mcneil L, Omar N (2014) Model for predicting disinfection by-product (DBP) formation and occurrence in intermittent water supply systems: Palestine as a case study. Arab J Sci Eng 39: 5883-5893. https://doi.org/10.1007/s13369-014-1200-x

Haider H, Ghumman AR, Al-Salamah IS, Ghazaw Y, Abdel-Maguid RH (2019) Sustainability evaluation of rainwater harvesting-based flood risk management strategies: a multilevel decision-making framework for arid environments. Arab J Sci Eng 44:8465-8488. https://doi.org/10.1007/s13369-019-03848-0
Hussein MH, Othman AK (1988) Soil and water losses in a low intensity rainfall region in Iraq. Hydrol Sci J 33(3):257-267. https://doi.org/ 10.1080/02626668809491247

Ijaz MW, Siyal AA, Mahar RB, Ahmed W, Anjum MN (2017) Detection of hydromorphologic characteristics of Indus River Estuary, Pakistan, using satellite and field data. Arab J Sci Eng 42:25392558. https://doi.org/10.1007/s13369-017-2528-9

Khattak MS, Anwar F, Saeed TU, Sharif M, Sheraz K, Ahmed A (2016) Floodplain mapping using HEC-RAS and ArcGIS: a case study of Kabul River. Arab J Sci Eng 41:1375-1390. https://doi.org/10. 1007/s13369-015-1915-3

Krois J, Schulte A (2014) GIS-based multi-criteria evaluation to identify potential sites for soil and water conservation techniques in the Ronquillo watershed, northern Peru. Appl Geogr 51:131-142. https://doi.org/10.1016/j.apgeog.2014.04.006

Mahmoud WH, Elagib NA, Gaese H, Heinrich J (2014) Rainfall conditions and rainwater harvesting potential in the urban area of Khartoum. Resour Conserv Recycl 91:89-99. https://doi.org/10. 1016/j.resconrec.2014.07.014

McCredie MN, Quinn CA, Covington M (2017) Dialectical behavior therapy in adolescent residential treatment: outcomes and effectiveness. Resid Treat Child Youth 34:84-106. https://doi.org/10.1080/ 0886571X.2016.1271291

Najmaddin PM, Whelan MJ, Balzter H (2017) Application of satellitebased precipitation estimates to rainfall-runoff modelling in a datascarce semi-arid catchment. Climate 5(2):32. https://doi.org/10. 3390/cli5020032

Prasad HC, Bhalla P, Palria S (2014) Site suitability analysis of water harvesting structures using remote sensing and GIS - a case study of Pisangan watershed, Ajmer district, Rajasthan. In: International Archives of the Photogrammetry, Remote Sensing and Spatial Information Sciences - ISPRS Archives, pp 1471-1482

Sayl KN, Muhammad NS, Yaseen ZM, El-shafie A (2016) Estimation the physical variables of rainwater harvesting system using integrated GIS-based remote sensing approach. Water Resour Manag 30: 3299-3313. https://doi.org/10.1007/s11269-016-1350-6

Vijayakrishnan SK, Mandla VR, Pannem RMR (2016) A geospatial approach for the development of hazardous building zonation mapping. Arab J Sci Eng 41:1329-1341. https://doi.org/10.1007/ s13369-015-1873-9

Wen Z, Xiong Z, Lu H, Xia Y (2019) Optimisation of treatment scheme for water inrush disaster in tunnels based on fuzzy multi-criteria decision-making in an uncertain environment. Arab J Sci Eng 44: 8249-8263. https://doi.org/10.1007/s13369-019-03827-5

Zakaria S, Al-Ansari NA, Dawood AH, Knutssson S (2014) Future prospects for macro rainwater harvesting technique at Northwest Iraq. J Earth Sci Geotech Eng 4(1):1-16

Zakaria S, Al-Ansari NA, Knutsson S (2012) Rain water harvesting and supplemental irrigation at northern Sinjar Mountain, Iraq. J Pur Util React Environ 1(3): 121-141

Zakaria S, Al-Ansari N, Knutsson S (2013) Rainwater harvesting using recorded and hypothetical rainfall data scenarios. J Earth Sci Geotech Eng 3(2):21-42

Zakaria S, Al-Ansari NA, Mustafa Y, Mohammed DA, Knutsson S, Ahmed P, Ghafour B (2013) Rainwater harvesting at Koysinjaq (Koya), Kurdistan Region, Iraq. J Earth Sci Geotech Eng 3(4):25-46 